\title{
UČINCI TROŠARINA NA ZASLAĐENE BEZALKOHOLNE NAPITKE NA PREVENCIJU I KONTROLU PRETILOSTI
}

Sažetak: $\quad$ Cilj u radu provedenih istraživanja je utvrditi razloge uvođenja oporezivanja proizvodnje/prodaje zasladenih bezalkoholnih napitaka, trenutačnu globalnu rasprostranjenost ovih trošarina prema poreznim područjima te njihovu učinkovitost ponajprije s aspekta prevalencije pretilosti i njezinih komorbiditeta. Trošarine na zaslađene bezalkoholne napitke su instrument porezne politike koji se koristi radi prevencije i kontrole pretilosti. Pretilost je klinički, javnozdravstveni i ekonomski veoma opasna bolest od koje već boluje više od 600 milijuna ljudi širom svijeta. Od uvođenja trošarina na ove napitke, ali i na drugu "nutritivno praznu" hranu, očekuju se pozitivne promjene u ponašanju i odnosu potrošača prema strukturi vlastite prehrane i osobnom zdravlju. Naime kalorije iz zasladenih bezalkoholnih napitaka su značajan izvor dodanih kalorija u prehrani suvremenog čovjeka na globalnoj razini i kao takve utječu na prekomjerni unos kalorija, a što je podloga za razvoj pretilosti. Više cijene oporezovanih napitaka trebale bi dovesti do pada potrošnje i posljedično nižeg kalorijskog unosa te do smanjenja prevalencije pretilosti. Uvođenje trošarina na zaslađene napitke također može povećati porezne prihode iz kojih se mogu financirati rastući javnozdravstveni troškovi uzrokovani pretilošću i pratećim bolestima. Porezni prihodi mogu poslužiti i za subvencioniranje prehrane najsiromašnijih i proizvodnje nutritivno kvalitetnije hrane. Trošarinama uzrokovan pad potražnje primorao bi i proizvođače zaslađenih napitaka na poboljšanje recepture i asortimana. Uvođenje trošarina na zaslađene napitke nije bespogovorno prihvaćeno, a osporavatelji dovode u pitanje ostvarivanje očekivanih prehrambenih, zdravstvenih, financijskih i socijalnih učinaka trošarina. Burnoj debati pro et contra uvođenja trošarina na zaslađene napitke pridonose ambivalentni rezultati analiza učinkovitosti ovih poreza.

Ključne riječi: $\quad$ fiskalna politika, prevalencija pretilosti, posljedice pretilosti, zaslađeni napitci, učinci trošarina

\footnotetext{
* Dr. sc. Rajko Odobaša, izvanredni profesor na Katedri gospodarskih znanosti Pravnog fakulteta Sveučilišta Josipa Jurja Strossmayera u Osijeku, Stjepana Radića 13, 31000 Osijek, Republika Hrvatska. Adresa e-pošte: rodobasa@pravos.hr. ORCID: https://orcid.org/0000-0002-3438-3893.
} 


\section{UVODNE NAPOMENE I RAZMATRANJA}

Iako i dalje oko 800 milijuna ljudi nema dovoljno hrane, među kojima je oko 500 milijuna kronično pothranjenih, u svega nekoliko posljednjih desetljeća razvio se novi, galopirajući i globalno rasprostranjen javnozdravstveni i društveni problem povezan s prekomjernom konzumacijom hrane. Prevelika količina unesenih kalorija u odnosu na njihovu potrošnju dovodi do pretilosti, bolesti koja je klinički, javnozdravstveno i socioekonomski veoma opasna. Od ove bolesti 2014. g. je bolovalo više od 600 milijuna ili 13 posto (11 posto muškaraca i 15 posto žena) odraslih osoba diljem svijeta. Ako pretilima pribrojimo osobe s povećanom tjelesnom masom, dolazi se do broja od oko 1,9 milijardi ljudi, odnosno 39 posto odraslih koji imaju probleme povezane s povećanom tjelesnom masom. Prevalencija pretilosti se od 1980. g. do danas udvostručila na globalnoj razini, a sličnu pandemiju epidemiolozi nisu zabilježili u moderno doba.

Dok je nekad pretilost smatrana isključivo problemom razvijenih zemalja, danas se ova bolest proširila na srednje i slabo razvijene zemlje. Većina svjetske populacije već sada živi u zemljama i regijama u kojima povećana tjelesna masa i pretilost više utječu na preuranjenu smrtnost nego štetne posljedice pothranjenosti. Pretilost ipak najteže pogađa djecu, a na globalnoj razini je više od 41 milijun djece ispod pete godine života preuhranjeno ili pretilo.

Prema trenutačnom trendu rasta, procjenjuje se kako bi do 2025. godine petina odraslih osoba na svijetu mogla biti pretila ili s povećanom tjelesnom masom. Zbog poražavajućih prognoza, javne politike diljem svijeta nastoje raznorodnim aktivnostima djelovati na prevenciji i kontroli širenja pretilosti. Nažalost, sve dosadašnje preporuke i aktivnosti epidemiologa, nutricionista, endokrinologa, gastroenterologa, psihijatara, psihologa, fizijatara, kirurga, ekonomista, demografa, sociologa, pravnika i drugih struka u svezi s prevencijom i kontrolom pretilosti nisu zaustavile rast prevalencije pretilosti.

Jedan od načina prevencije i kontrole pretilosti je uvođenje trošarina na zaslađene bezalkoholne napitke (SSBs - sugar sweetened beverages) kao glavnog izvora suvišnih kalorija koje dovode do povećane tjelesne mase i pretilosti. Od oporezivanja SSB-a očekuje se utjecaj na pozitivne promjene u prehrambenim navikama potrošača i preorijentiranje na nutritivno kvalitetnije napitke, ali i kod proizvođača u vidu povećane brige o kvaliteti njihovih proizvoda i zdravlju potrošača. Uvođenje trošarina na SSB-e kao posebnog oblika poreza na promet također povećava fiskalne prihode države i raspoloživa sredstva nužna za financiranje sve većih zdravstvenih troškova prevencije i liječenja pretilosti i pratećih bolesti.

Uz opis kliničke slike pretilosti, objašnjenja raznorodnih i međusobno kompleksno povezanih uzroka pretilosti, pandemijske prevalencije i opasnih posljedica pretilosti, u radu se analiziraju razlozi i ciljevi uvođenja trošarina na SSB-e u sve brojnijim poreznim područjima širom svijeta, kao i ostvareni učinci trošarina na prevenciju i kontrolu pretilosti. Analiza obuhvaća i prevalenciju povećane tjelesne mase i pretilosti u Hrvatskoj, kao i procjenu učinka posebnog poreza na bezalkoholna pića na njihovu potrošnju i stanje uhranjenosti stanovništva.

Pri istraživanju korištene su ekonomska i politekonomska metoda, statistička metoda, metoda sustavnog pregleda, pravna metoda, komparativna metoda i metoda predviđanja. 
Cilj rada je upozoriti na raznovrsne uzroke i zdravstvene te socioekonomske probleme povezane s pretilošću kao veoma raširenom i opasnom bolesti, ali i ukazati na potrebu provođenja raznorodnih mjera prevencije i kontrole pretilosti s posebnim naglaskom na preventivne javnozdravstvene i druge ciljeve te učinke uvođenja trošarina na SSB-e.

\section{KLINIČKA SLIKA, POSLJEDICE, GLOBALNA RASPROSTRANJENOST I ČIMBENICI RIZIKA ZA RAZVOJ PRETILOSTI}

Svjetska zdravstvena organizacija (WHO) zdravlje definira kao "stanje potpunog tjelesnog, mentalnog i društvenog blagostanja i više od samog odsustva bolesti ili patnje". ${ }^{1}$ Zdravstveno stanje populacije se mjeri i analizira s pomoću međusobno povezanih zdravstvenih indikatora, kao što su npr. pokazatelji pobola od kroničnih i zaraznih bolesti, očekivano trajanje života po rođenju (dugovječnost) i stopa mortaliteta. Zdravstveni status stanovnika je vjerojatno najvažniji pokazatelj dosegnutog stupnja društveno-ekonomskog razvoja i stabilnosti nekog društva, ali i temeljna determinanta ekonomskog, socijalnog, demografskog, kulturalnog i svakog drugog budućeg razvoja.

$\mathrm{Na}$ zdravstveni status stanovnika utječu brojni čimbenici, npr. biološki, ekološki, socioekonomski, kulturalni, zdravstveni itd. Među važne determinante zdravstvenog statusa ubrajaju se i epidemije zaraznih i nezaraznih bolesti, a pandemijske proporcije pretilosti, premda nezarazne bolesti, slijede obrasce širenja zaraznih bolesti. WHO pretilost svrstava u skupinu najtežih izazova za čovječanstvo u ovom stoljeću.

Pretilost je stanje prekomjernog nakupljanja masnog tkiva u organizmu zbog prekomjernog unosa energije (kalorija) u odnosu na potrošnju. Prema WHO-u stupanj uhranjenosti odrasle osobe mjeri se "indeksom tjelesne mase" (engl. Body mass Index - BMI, hrv. Indeks tjelesne mase - ITM, predstavlja omjer tjelesne mase u kilogramima i tjelesne visine u metrima na kvadrat), prema kojem je vrijednost ITM-a od 18,5 do $24,9 \mathrm{~kg} / \mathrm{m}^{2}$ normalna uhranjenost, vrijednost ITM-a od 25 do 29,9 pripada u kategoriju povećane tjelesne mase (overweight), a sve vrijednosti od 30 i više ulaze u kategoriju pretilosti (obesity), odnosno vrijednosti iznad $40 \mathrm{~kg} /$ $\mathrm{m}^{2} \mathrm{u}$ kategoriju ekstremne pretilosti. ${ }^{2}$

Oba stanja preuhranjenosti povećavaju rizik za razvoj brojnih akutnih i kroničnih bolesti, od dijabetesa tipa 2, hipertenzije, kardiovaskularnih bolesti, opstruktivne bolesti pluća, astme, gastritisa, velikog broja karcinoma, bolova u zglobovima do depresije i drugih bolesti. Povećana tjelesna masa i pretilost znatno smanjuju kvalitetu života i očekivano trajanje života kod oboljelih. Rizici se povećavaju s rastom vrijednosti ITM-a, a danas u svijetu već 1,9 milijar-

1 Smolić, Š., Zdravstveni sustav, u: Obadić, A., Tica J., (ur.) Gospodarstvo Hrvatske, Ekonomski fakultet u Zagrebu, Zagreb, 2016., str. 472 .

2 Za određivanje stanja uhranjenosti odraslih koriste se i druge metode uz BMI, npr. mjerenje opsega struka i mjerenje debljine kožnog nabora. Za osobe mlađe od 18 godina koriste se drukčiji kriteriji, tzv. percentilne krivulje. Prekomjernu tjelesnu masu imaju djeca čiji je BMI između 85 i 95 percentila, a pretila su ona s BMI-em većim od 95 percentila za životnu dob. 
di ljudi ili 39 posto odraslih ima povećani ITM. ${ }^{3}$ Istraživanja pokazuju da između 60 i 80 posto pretilih odraslih osoba, ovisno o stupnju pretilosti, boluje od dijabetesa tipa 2, hiperlipidemije, hipertenzije ili drugih komorbiditeta. Gotovo svaki četvrti novooboljeli od karcinoma i svaka treća smrt od karcinoma posljedica su povećane tjelesne mase i fizičke neaktivnosti. Procjene govore kako je na globalnoj razini pretilost glavni uzrok preuranjene smrti oko četiri milijuna ljudi (7,1 posto ukupno umrlih) na godinu. ${ }^{4}$

Najteži aspekt pandemije je porast učestalosti pretilosti u populaciji djece i adolescenata kod koje "predstavlja rani faktor rizika za morbiditet i mortalitet u odrasloj dobi". ${ }^{5}$ Broj djece s povećanom tjelesnom masom ili debljinom uzrasta do 5 godina porastao je u svijetu s 32 milijuna na više od 41 milijuna u razdoblju od 1990. do 2013. g. ${ }^{6}$ Podaci o prevalenciji među djecom i adolescentima posebice su zastrašujući u pojedinim zemljama i regijama svijeta, npr. stopa prevalencije je viša od 30 posto u Sjedinjenim Državama, 25 posto u Australiji i oko 20 posto u Europi. Od početka 1980-ih godina do danas prevalencija povećane tjelesne mase se više nego utrostručila kod američke djece između 6 i 11 godina života, a gotovo učetverostručila među onima u dobi između 12 i 19 godina života. Među ukupno 12,5 milijuna djece i adolescenata s prekomjernom tjelesnom masom njih gotovo 60 posto izloženo je najmanje jednom rizičnom čimbeniku za kardiovaskularnu bolest. Predijabetes i dijabetes tipa 2, ranije dijagnosticiranih samo kod odraslih osoba, danas ima četvrtina američkih adolescenata. ${ }^{7}$ Ipak, velika većina od 42 milijuna djece živi u slabije ili srednje razvijenim zemljama, a gotovo polovica od ukupnog broja u Aziji. Broj djece s povećanom tjelesnom masom i debljinom u Africi se udvostručio u razdoblju od 1990. do 2014. g., s 5,4 milijuna na 10,6 milijuna. ${ }^{8}$

Premda oboljeli i društvo ovu bolest redovito podcjenjuju, pretile osobe uz teške fiziološke trpe i ozbiljne psihosocijalne i ekonomske posljedice. Oboljelim osobama prijeti socijalna marginalizacija kao posljedica društvene stigmatizacije i diskriminacije, a takva situacija izaziva emocionalne poremećaje, gubitak samopouzdanja, pojavu anksioznosti, depresije i stresa. Uz to što su socijalno isključene, pretile osobe često imaju ozbiljne financijske probleme i niži životni standard uzrokovan smanjenom radnom produktivnošću, otežanim zapošljavanjem i povećanim troškovima za hranu, odjeću, programe i pripravke za mršavljenje, liječenje, osiguranje itd.

Pretilost predstavlja značajan javnozdravstveni problem koji se očituje u rastućim zdravstvenim troškovima i pritisku na proračunske izdatke. Procjenjuje se npr. da u Sjedinjenim Državama godišnji zdravstveni trošak povezan s pretilošću i pratećim bolestima iznosi između 147 i 210 milijardi dolara, što predstavlja 5 do 10 posto ukupne zdravstvene potrošnje.

3 Prema procjeni McCinsey Global instituta 2014. g. je čak 2,1 milijarda osoba imalo povećanu tjelesnu masu ili pretilost. Dobbs, R., Sawers, C., Thompson, F. et al., Overcoming Obesity: An Initial Economic Analysis, discussion paper, McKinsey Global Institute, London-San Francisco-Shanghai, 2014., str. 1.

4 World Health Organisation, Controlling the global obesity epidemic, 2017., www.who.int/nutrition/topics/ obesity/en/, pristupljeno 20. veljače 2017.

5 Toromanović, A., Liječenje pretilosti adolescenata, u: Bekavac-Bešlin, M., Pašić, F. i suradnici, (ur.) Kirurško liječenje bolesti debljine, Zagrebački institut za kulturu zdravlja, Zagreb - Tuzla, 2017., str. 181.

6 Ibidem.

7 Sweet Act, Sugar-Sweetened Beverages Tax Act of 2015, H. R. 1687, https://www.congress.gov/114/bills/hr 1687/BILLS114hr1687ih.xml., pristupljeno 30. siječnja 2017.

8 Musić Milanović, S., Delaš, M., Debljina i čimbenici rizika, u: Bekavac-Bešlin, M., Pašić, F. et al., (ur.) Kirurško liječenje bolesti debljine, Zagrebački institut za kulturu zdravlja, Zagreb - Tuzla, 2017., str. 166.-167. 
Zdravstveni troškovi rastu jer liječenje rastućeg broja pretilih u prosjeku stoji 42 posto više nego liječenje normalno uhranjenih osoba istog životnog doba i spola. ${ }^{9}$ Kao posljedica rastućih stopa pretilosti danas u Europi od dijabetesa boluje 57 milijuna ljudi (8,5 odrasle populacije), a njihovo liječenje je 2010. g. stajalo oko 105,5 milijardi američkih dolara na godinu. Uz dijabetes i druge popratne bolesti pretilost često uzrokuje gubitak radnih sati, nezaposlenost i preuranjenu smrt, a to umanjuje agregatnu produktivnost, porezne prihode i stope gospodarskog rasta. Ukupni svjetski financijsko-ekonomski trošak nastao kao posljedica pandemije pretilosti procjenjuje se na oko 2 bilijuna dolara na godinu ili 2,8 posto svjetskog bruto društvenog proizvoda. ${ }^{10}$

Za razliku od prevalencije drugih kroničnih nezaraznih bolesti koje se smanjuju, globalne stope pretilosti kontinuirano rastu. Globalno debljanje ljudske populacije (globesity) potvrđuje podatak kako je u razdoblju između 1975. i 2014. godine u svijetu prosječni globalni ITM za muškarce i žene svako desetljeće rastao ekvivalentu od 1,5 kg dodatne tjelesne mase po osobi. U okviru ovog trenda Sjedinjene Države, Velika Britanija, Australija, Irska i Kanada, visoko razvijene zemlje engleskog govornog područja, imaju jednu od najbržih stopa rasta ITM-a. Štoviše, u njima živi više od četvrtine od ukupnog broja ekstremno ili morbidno pretilih ljudi na svijetu. ${ }^{11} \mathrm{U}$ Australiji više od 60 posto odraslih ima povećanu tjelesnu masu i pretilost, a pretilost je kao vodeći čimbenik rizika za obolijevanje od kroničnih nezaraznih bolesti i preuranjene nenasilne smrti pretekla pušenje. ${ }^{12} \mathrm{Uz}$ Kinu i Indiju, Sjedinjene Države trenutačno imaju najveći broj pretilih stanovnika, a pretili Amerikanci čine 13 posto od ukupnog broja pretilih osoba u svijetu. Prema nacionalnom Centru za kontrolu i prevenciju bolesti (Centers for Disease Control and Prevention), 2012. g. više od jedne trećine ili 34,9 posto odraslih i 17 posto djece i mladih uzrasta od 2 do 19 godina bilo je pretilo. Trend rasta prevalencije pretilosti među odraslima u međuvremenu se nastavio i 2016. g. postotak pretilih skočio je na 38 posto. Više od 5 posto muškaraca i gotovo 10 posto žena pripada u skupinu patološki pretilih. ${ }^{13}$

Podaci o regionalnoj prevalenciji pretilosti pokazuju da je problem posebno izražen na Srednjem istoku, u sjevernoj Africi, srednjoj Americi i otočkim zemljama u Pacifiku. U njima je stopa prevalencije povećane tjelesne mase i pretilosti 2013. g. već dosegnula 44 posto, pri čemu su u većini zemalja ovih regija stope odraslih osoba s povećanom tjelesnom masom i debljinom iznad 50 posto. ${ }^{14} \mathrm{U}$ sjevernoameričkoj regiji stopa odraslih osoba s povećanom tjelesnom masom i debljinom iznosi 26,8 posto, dok je u europskoj regiji 23 posto. Stopa pretilih

9 Goozner, M., Unchecked Obesity Rates Could Bankrupt Nation, The Fiscal Times, 2012, http://www.thefiscaltim es.com/ Articles/2012/09/19/Unchecked-Obesity-Rates-Could-Bankrupt-Nation, pristupljeno 5. srpnja 2017.

10 Dobbs, R. et al., op. cit. u bilj. 3.

11 National Health Service (England), Global Obesity Rates Expected to Soar in Next Decade, https://www.nhs.uk/news/2016/04April/ Pages/Global-obesity-rates-expected-to-soar-in-next-decade.aspx, pristupljeno 20. veljače 2017. U Engleskoj je 26 posto odraslih osoba pretilo, među kojima je 2 posto muškaraca i 4 posto žena ekstremno pretilo. Engleske NHS bolnice su 2016./2017. g. primile 617.000 pacijenata čija je primarna ili sekundarna dijagnoza bila pretilost, što predstavlja povećanje od 18 posto u odnosu na 2015./2016. g.

12 University of Sydney, Could a sugary drinks tax improve Australian diets?, http://sydney.edu.au/news-opinion/news/2016/03/18/ could-a-sugary-drinks-tax-improve-australian-diets-.html, pristupljeno 20. prosinca 2016.

13 Fox, M., America's Obesity Epidemic Hits a New High, NBC News, 2016, https://www.nbcnews.com/health/health-news/americas-obesity-epidemic-hits-new-high-n587251, pristupljeno 21. srpnja 2017.

14 IHME - Institute for Health Metrics and Evaluation, Nearly One-third of the World's Population is Obese or Overweight, New Data Show, http://www.healthdata.org/news-release/nearly-one-third-world\%E2\%80\%99s-population-obese-or-overweight-new-datashow, pristupljeno 20. srpnja 2017. 
odraslih osoba u Africi je 10,4 posto, dok je u jugoistočnoj Aziji ova stopa oko 5 posto. ${ }^{15}$ Više od pedeset posto globalnog broja pretilih osoba živi u deset zemalja: Sjedinjenim Državama, Kini, Indiji, Rusiji, Brazilu, Meksiku, Egiptu, Njemačkoj, Pakistanu i Indoneziji. ${ }^{16}$ Razvidno je kako, nasuprot ranijim očekivanjima, kretanja u prevalenciji pretilosti nisu ograničena samo na visoko razvijene zemlje. Od više od 600 milijuna pretilih osoba u svijetu njih više od 115 milijuna živi u srednje i slabije razvijenim zemljama. Ekstrapolacija postojećih trendova sugerira kako će do 2025. g. petina odraslih osoba na svijetu biti pretila, pri čemu će najteže biti pogođene odrasle osobe u razvijenim zemljama i zemljama Latinske Amerike i Kariba.

U epidemiološkom smislu stopa prevalencije povećane tjelesne mase i pretilosti u Hrvatskoj također zabrinjava, posebno kod djece i mladih. Naime, prema istraživanju European Health Interview Survey - EHIS 2013-2015. g. 38 posto stanovnika ima povećanu tjelesnu masu, dok je 18 posto pretilo. Prema procjeni Global status report on noncommunicable disease za 2014. g. u Hrvatskoj je prekomjernu tjelesnu masu imalo 58,47 posto starijih od 18 godina, među kojima je 20,4 posto pretilo. ${ }^{17}$ Međunarodno istraživanje provedeno 2014. g. u više od 40 zemalja i regija Europe i svijeta utvrdilo je kako je u Hrvatskoj više od četvrtine djece preuhranjeno ili pretilo. U tek deset zemalja obuhvaćenih istraživanjem ima više pretilih učenika u dobi od 11 godina nego u Hrvatskoj. ${ }^{18}$ Zbog rastućih stopa prevalencije pretilosti u Hrvatskoj kontinuirano rastu zdravstveni troškovi, primjerice dijabetes kod 241.990 registriranih bolesnika (2013. g.) i liječenje njegovih komplikacija društvo stoji na godinu oko 2,5 milijarde kuna ili 11,5 posto proračuna Hrvatskog zavoda za zdravstveno osiguranje. ${ }^{19}$

Pojednostavnjeno, pretilost je rezultat disbalansa u pogledu unosa i potrošnje energije. No, u temeljima pretilosti nalazi se više raznorodnih uzročnika i njihova kompleksna međudjelovanja. Među uzročnicima pretilosti primarni utjecaj imaju socioekonomski i bihevioralni čimbenici, ali se pretilost može razviti i pod utjecajem bioloških, genetskih, ekoloških, psiholoških i farmakoloških čimbenika. Načelno pogađa pripadnike svih socioekonomskih, obrazovnih, spolnih, dobnih, etničkih i drugih društvenih skupina, ali kod pripadnika skupina nižeg socioekonomskog i obrazovnog statusa, etničkih manjina i jednoroditeljskih obitelji rizici za obolijevanje su izraženiji. Uz uvažavanje individualnih razlika u razlozima obolijevanja od pretilosti, valoriziranje uzročnika pretilosti prema njihovoj utjecajnosti ima veliki značaj pri izradi javnozdravstvenih preporuka, planova i strategija prevencije i kontrole pretilosti. ${ }^{20}$

Političke, ekonomske, socijalne i tehnološke promjene koje su u drugoj polovini 1970-ih godina zahvatile zapadne razvijene zemlje dovele su do brze tranzicije prehrambenih navika i strukture prehrane stanovnika prema prekomjernom unosu hrane bogate kalorijama, ali niske nutritivne vrijednosti. Među stanovništvom sve više se širila prehrana u čijoj strukturi značajan dio kalorija dolazi kroz konzumaciju brzih, gotovih i polugotovih jela, grickalica, raznih pekarskih proizvoda, sladoleda, zaslađenih bezalkoholnih napitaka i druge hrane s visokim udjelom

15 Musić Milanović, S. et. al., op. cit. u bilj. 8, str. 166.

16 IHME - Institute for Health Metrics and Evaluation, op. cit. note 14.

17 Musić Milanović, S. et. al., op. cit. u bilj. 8, str. 168.-169.

18 Ibidem, str. 167.-168.

19 Bobinac, Ana, Zdravlje je neprocjenjivo, zdravstvo ima cijenu. Znamo li ju izračunati?, Jutarnji list, 24. lipnja 2017., str. 28.-29. Dijabetes je u Hrvatskoj osmi uzrok smrtnosti, a od njega boluje svaka peta osoba iznad 65 godina te svaka deseta iznad 18 godina. 
šećera i masti (čija jedinična cijena desetljećima kontinuirano opada). Takva struktura prehrane predstavlja podlogu na kojoj najbrže dolazi do razvoja pretilosti i pratećih bolesti. Premda su kalorije unesene kroz ovu prehranu "prazne" (zatomljuju glad nakratko, a nedostaju minerali i vitamini), potrošačko-prehrambena opcija utemeljena na kaloričnoj i jeftinoj hrani najprivlačnija je i kratkoročno najisplativija osobama/kućanstvima s niskim socioekonomskim statusom. Ovaj način prehrane kratkoročno rješava njihov problem nedostatka novca za nutritivno kvalitetniju hranu, posebno u zemljama u kojima je oštra primjena politike slobodnih tržišta rezultirala porastom stopa siromaštva i ekonomske nejednakosti. ${ }^{21}$ Naravno da loše strukturirana prehrana i nezdrave prehrambene navike dugoročno negativno djeluju na zdravstveni status stanovnika, ali i doprinose progresivnom rastu zdravstvenih i ekonomskih troškova društva. Razvoju pretilosti i pratećih bolesti pogoduje i niski obrazovni status koji značajno otežava informiranje o nutritivno kvalitetnim namirnicama, razvoj svijesti o štetnim zdravstvenim posljedicama pogrešne strukture prehrane i nužne promjene u prehrambenim navikama. ${ }^{22}$ Štetnim posljedicama prehrambene tranzicije doprinosi i suvremena tehnologija (produljeno vrijeme sjedenja uz računalo, televizor i u prijevoznim sredstvima), udobnost prehrane (dostava hrane u kuću, drive-in prehrana, prehrana u restoranima) i smanjenje fizičke aktivnosti, tj. sjedilački način života (sedentary lifestyle). ${ }^{23}$ Povećano sudjelovanje žena na tržištu rada i slabljenje njihove tradicionalne uloge u prehrani obitelji (posebno djece) također olakšava usvajanje loših prehrambenih navika (preskakanje obroka i prehrana izvan kuće), konzumiranje nutritivno nekvalitetne hrane i stvaranje podloge pogodne za razvoj pretilosti. Štetne promjene u navikama i strukturi prehrane i sjedilački način života, uz pogrešne poljoprivredno-prehrambene politike (orijentirane isključivo prema profitu), već se desetljećima iz zapadnih razvijenih zemalja, epicentra pandemije pretilosti, šire na sve druge dijelove svijeta s istim rezultatima. Rasprostiranju zapadnih obrazaca prehrane (uniformizacija prehrane) i načina života (amerikanizacija svakodnevice) na slabije i srednje razvijene zemlje pogoduju mehanizmi ekonomske, političke, kulturalne i tehnološke globalizacije, ali i želja slabije razvijenih da vlastiti društveno-ekonomski razvoj ubrzaju kroz oponašanje zapadnog ekonomskog i političkog modela.

Ipak, u pozadini socioekonomskih i bihevioralnih uzročnika pandemije pretilosti nalazi se rast materijalnog bogatstva svijeta i revolucionarni napredak poljoprivredno-prehrambene tehnologije u posljednjih šezdesetak godina. Progres je prehranu učinio obilnijom, sigurnijom i kaloričnijom, a to na globalnoj razini znači da je u razdoblju od 1960. do 1990. g. dnevni unos kalorija povećan za $450 \mathrm{kcal}$, a u zemljama u razvoju za čak $600 \mathrm{kcal} .{ }^{24}$ Prema podacima FAO-a prosječni dnevni unos kalorija na globalnoj razini u 2010. godini iznosio je $2.780 \mathrm{kcal}$, pri čemu su stanovnici razvijenih zemalja prosječno na dan unosili $3.420 \mathrm{kcal}$, a stanovnici zemalja u razvoju $2.630 \mathrm{kcal}^{25}$

21 Drewnowski, A., Obesity, Diets, and Social Inequalities, Nutrition Reviews, god. 67 (Suppl. 1), 2009., str. 536.

22 Niže stope prevalencije pretilosti kod stanovništva s višim socioekonomskim i obrazovnim statusom ne znači da među onima koji si financijski mogu priuštiti nutritivno kvalitetnu i uravnoteženu prehranu nema popriličan broj nedovoljno obrazovanih u pogledu nutritivne kvalitete prehrane i zdravih prehrambenih navika, kao i štedljivih koji hotimice kupuju manje kvalitetne namirnice ili potpuno nemarnih u pogledu vlastite prehrane i prehrambenih navika.

23 Drewnowski, A., Fat and Sugar: An Economic Analysis, The Journal of Nutrition, god. 133, br. 3, 2003., str. 838.

24 Musić Milanović, S. et. al., op. cit. u bilj. 8, str. 164.

25 Dnevni unos kalorija u Sjedinjenim Državama je u razdoblju između 1971. i 2000. g. porastao za 530 kalorija ili 24,5 posto. Amerikanci su 2000. g. unosili prosječno oko 3.800 kalorija na dan, odnosno 800 kalorija više nego u godinama 1957. - 1958. Ipak, rast unesenih kalorija u gotovo dvadesetogodišnjem razdoblju od 1960-ih do kasnih 1970-ih godina nije za posljedicu imao povećanje prevalencije pretilosti. U tom razdoblju pretilost je relativno konstantna i iznosi oko 15 posto stanovništva. Centers 
Bez obzira na obilje dostupnih globalnih zaliha hrane (što pothranjenost stanovništva u nekim dijelovima svijeta čini još skandaloznijom), poljoprivredno-prehrambeni sektor mora nastaviti povećavati proizvodnju kako bi opstao i stvarao profit. Kako bi to postigao, mora stvoriti tip potrošača koji će prehrambene proizvode kontinuirano kupovati i trošiti. Funkciju povezivanja ponude i potražnje u tržišnim gospodarstvima najučinkovitije obavlja danas sveprisutni konzumerizam, nova vrsta "emancipacijske" etike koja je golemoj većini ljudi u ranijim vremenima oskudice bila nepoznata, moralno odbojna ili čak zabranjena. Stupanj uspješnosti konzumerističke etike vidi se i kod prehrambenog konzumerizma koji potiče globalni rast prosječnog dnevnog unosa kalorija: “Tradicionalna su agrarna društva živjela u stalnoj i strašnoj sjeni gladi. U imućnom svijetu današnjice, vodeći je zdravstveni problem pretilost, koja sirotinju (koja se trpa hamburgerima i picama) udara još gore nego bogatune (koji jedu organsku salatu i piju frape). Svake godine američki stanovnici potroše više novaca na dijetu no što bi dostajalo da se nahrane svi gladni ostatka svijeta. Pretilost je stoga za konzumerizam dvostruka pobjeda. Umjesto da ljudi jedu manje, što bi dovelo do ekonomske kontrakcije, oni jedu previše i onda kupuju dijetalne proizvode - dajući tako dvostruki doprinos gospodarskom rastu." ${ }^{26}$

\section{TROŠARINE NA ZASLAĐENE BEZALKOHOLNE NAPITKE KAO MJERA PREVENCIJE I KONTROLE PRETILOSTI TE NJIHOVI JAVNOZDRAVSTVENI I DRUGI UČINCI}

Pretilost je kronična bolest kod koje smanjivanje tjelesne mase pacijenta najčešće traje veoma dugo. Lijek protiv debljine ne postoji, a u liječenju pretilosti poduzimaju se različite farmakoterapijske, psihoterapijske i socioterapijske intervencije. Najbolje rezultate u liječenju pretilosti i dijabetesa tipa 2 u posljednjih petnaestak godina postiže barijatrijska kirurgija (kirurgija želuca), kako u pogledu fizičkih promjena tako i zbog pozitivnog utjecaja na psihu bolesnika. ${ }^{27}$

Zbog pandemijskih razmjera, sporog i skupog liječenja borba protiv pretilosti nužno se orijentira na njezinu prevenciju i kontrolu. Među mjere od kojih se očekuje doprinos sprječavanju pobola od pretilosti pripada i oporezivanje proizvodnje/prodaje SSB-a, ${ }^{28}$ odnosno uvođenje trošarina ( $a k c i z a)$ na ove napitke. U suvremenim poreznim sustavima trošarinama se često oporezuju upravo proizvodi čija se potrošnja drži štetnom za zdravlje (npr. duhan) ili za

for Desease and Prevention - Morbidity and Mortality Weekly Report, Trends in Intake of Energy and Macronutritients - United States, 1971 - 2000, https://www.cdc.gov/mmwr/preview/mmwrhtml/mm5304a3.htm., 2004., pristupljeno 24. srpnja 2017. Prema količini na dan prosječno unesenih kalorija iza stanovnika Sjedinjenih Država (3.770) slijede stanovnici Austrije (3.760), zatim Italije (3.660), Izraela (3.540), Irske (3.530), Velike Britanije (3.440), Češke (3.320), Novog Zelanda (3.150), Argentine (3.000) itd. Usporedimo li ove podatke s preporučenim maksimalnim dnevnim količinama za muškarce (2.500) i žene (2.000) vidi se količina prekomjerno unesenih kalorija. Peppers, M., Daily Calorie Intake of Coutries Across the World Revealed... and (surprise) the U.S. Tops the List at 3.770., Mailonline, http://www.dailymail.co.uk/femail/article-2722815/Daily-calorie-intakecountries-world-revealed-surprise-U-S-tops-list-3-770.html., 2014., pristupljeno 18. srpnja 2017.

Harari, Y. N., Sapiens - kratka povijest čovječanstva, Fokus komunikacije, Zagreb, 2015., str. 385.-387.

Đorđević, V., Braš, M., Psihološki aspekti barijatrijske kirurgije, u: Bekavac-Bešlin, M., Pašić, F. et al., (ur.) Kirurško liječenje bolesti debljine, Zagrebački institut za kulturu zdravlja, Zagreb - Tuzla, 2017., str. 173.

U šećerom (ili kukuruznim sirupom) zaslađene napitke pripadaju bezalkoholna pića s energetskim sladilima, energetska pića, slatki čajevi i kave, sportski napitci itd. Zaslađeni napitci sadrže velike količine fruktoze, a imaju malo ili nimalo hranjive vrijednosti. Zaslađeni bezalkoholni napitci nisu jedini izvor dodanih šećera u suvremenoj prehrani, to su i sladoled, čokolada, keksi, zaslađene žitarice za doručak, žitne pločice, pudinzi, zaslađeni jogurti itd. 
prirodni okoliš (npr. motorna goriva), odnosno nemoralnom (npr. igraće karte). Budući da potrošači nemaju dovoljno istinitih informacija (ili su iskrivljene marketingom) o štetnosti SSB-a po zdravlje i/ili volju za smanjivanje njihove potrošnje, trošarinama se kroz rast cijena nastoji destimulirati potrošnja SSB-a. ${ }^{29} \mathrm{U}$ tom smislu trošarine su "dobar instrument kojim se država koristi kako bi se uplela u izbor pojedinca, i pokušala ga pritjerati na veću brigu o zdravlju (...)" ${ }^{30}$ Od trošarina se očekuje doprinos kako na planu primarne (manji unos kalorija), tako i sekundarne prevencije (olakšavanje komorbiditetnih tegoba). Posebnu važnost trošarine imaju u prevenciji pretilosti kod djece i mladih (slaba predodžba budućih zdravstvenih tegoba) te osoba s nižim socioekonomskim statusom (njihova potražnja je cjenovno elastičnija). ${ }^{31}$

Uz zdravstvene razloge, trošarine se kao izdašni porez uvode kako bi se kroz povećanje poreznih prihoda osigurala dovoljna financijska sredstva za rastuće zdravstvene troškove generirane debljinom i pratećim bolestima. ${ }^{32}$ Trošarine su i dobar instrument pritiska na proizvođače SSB-a od kojih se očekuju proizvodi s manjim udjelom dodanih šećera i porast brige za zdravlje potrošača.

Konzumacija SSB-a smatra se štetnom za zdravlje zbog toga što su zbog značajnih količina šećera (fruktoze i glukoze) ovi napitci glavni izvor dodanih kalorija u prehrani suvremenog čovjeka na globalnoj razini. ${ }^{33}$ Štetne zdravstvene posljedice nastaju i zbog toga što konzumiranje SSB-a smanjuje unos zdravijih napitaka, kao i zbog toga što se povećani unos kalorija iz ovih napitaka ne kompenzira smanjivanjem kalorija unesenih hranom. Naime, zaslađeni napitci slabe kontrolu apetita i ne zatomljuju glad. S rastom količine na dan konzumiranih zaslađenih napitaka rastu i zdravstveni rizici kojima su potrošači izloženi. Analize pokazuju da odrasle osobe koje na dan piju jedno ili više SSB-a (oko $5 \mathrm{dcl}$ ) imaju 27 posto veću vjerojatnost za razvoj povećane tjelesne mase i pretilosti, bez obzira na socioekonomski ili obrazovni status. Uz dnevnu potrošnju jedne litre ili više, nakon šest mjeseci masne naslage u jetrima povećaju se za 150 posto, što izravno pridonosi nastanku dijabetesa i kardiovaskularnih bolesti. Dnevno konzumiranje prosječne količine dodanog šećera sadržane u 6 dcl SSB-a za 30 posto povećava vjerojatnost smrti od srčanog udara u idućih petnaest godina, a dnevna potrošnja prosječne količine dodanog šećera sadržane u dva do tri SSB-a od 6 dcl vjerojatnost povećava za 2,75

29 Kod trošarina na SSB preporučuje se plaćanje po gramu dodanog šećera po jedinici mjere proizvoda (ml ili l), a ne u postotku cijene kupljenog napitka (ad valorem). To je zato što ad valorem trošarine potiču kupnju jeftinijih proizvoda i kupnju na veliko (što ne bi utjecalo na smanjivanje energetskog unosa), kao i zbog toga što bi sirupi iz kojih se može dobiti više napitaka zapravo ostali neoporezovani. Od trošarina često se izuzimaju prirodni napitci od voća i povrća, kao i mliječni napitci. Trošarine na duhan, alkohol, SSB-e i druge društveno nepoželjne proizvode kolokvijalno se nazivaju "sin-tax". Brownell, K. D.; Farley, T.; Willet, W. C. et al., The Public Health and Economic Benefits of Taxing Sugar-Sweetened Beverages, The New England Journal of Medicine, god. 361, br. 16, 2009., 1599.-1605.

Šimurina, N.; Dražić Lutilsky, I.; Barbić, D.; Dragija Kostić, M., Osnove porezne pismenosti, Ekonomska biblioteka, Narodne novine, Zagreb, 2018., str. 98.

31 Sassi, F.; Belloni, A.; Mirelman, A. J., Equity Impacts of Price Policies to Promote Healthy Behaviours, The Lancet, Vol. 391, No. 10134, 2018., str. 2059.-2070.

32 Procjenjuje se da bi nacionalna trošarina od jednog centa po $30 \mathrm{ml}$ zaslađenog napitka Sjedinjenim Državama donijela oko 20 milijardi dolara poreznih prihoda na godinu.

33 Prema preporukama Svjetske zdravstvene organizacije zdrava prehrana ne bi trebala sadržavati dodane količine šećera povrh one koja se unosi kroz nutritivno uravnoteženu prehranu. Zbog toga bi se maksimalno 10 posto dnevnih potreba za kalorijama trebalo zadovoljavati unosom slobodnih šećera, a najbolje svega 5 posto. Boseley, S., ed. World Health Organisation Urges all Countries to Tax Sugary Drinks, www.theguardian.com/society/2016/oct/11/world-health-organisation-who-countries-taxsugary-drinks, pristupljeno 9. svibnja 2017. 
puta. ${ }^{34}$ Prema studiji iz 2010. g. pretjerano konzumiranje SSB-a može se povezati s 184.000 preuranjenih smrtnih ishoda na godinu na globalnoj razini, od kojih su 133.000 posljedica dijabetesa, 45.000 kardiovaskularnih bolesti i 6.450 karcinoma. Najviše je umrlih od bolesti povezanih s konzumacijom SSB-a u srednje razvijenim zemljama (70,9 posto), zatim u razvijenim zemljama ( 24,1 posto) te najmanje u slabo razvijenim zemljama (5 posto). ${ }^{35}$

U Sjedinjenim Državama svaki stanovnik na godinu prosječno popije oko 170 litara SSB-a, što je jednako kao da je konzumirao 17,6 kg dodatnog šećera svake godine. ${ }^{36}$ Prema Nacionalnom centru za zdravstvenu statistiku (National Center for Health Statistics), trećinu kalorija iz dodanih šećera (33 posto) odrasli unose kroz SSB-e, dok djeca i adolescenti čak 40 posto kalorija iz dodanih šećera dobivaju na ovaj način. Djeca i mladi iz SSB-a dobivaju prosječno između 10 i 15 posto ukupnog dnevnog kalorijskog unosa. Iako prosječna potrošnja SSB-a posljednjih nekoliko godina slabi, vjerojatno kao posljedica rasta informiranosti o njihovoj štetnosti, danas Amerikanci svih dobnih skupina i dalje konzumiraju dva puta više ovih napitaka nego tijekom 1970ih godina. ${ }^{37}$ Stanovnici Australije i Novog Zelanda prosječno konzumiraju oko 76 litara SSB-a na godinu, a posebno veliki potrošači su djeca i mladi među kojima oko 47 posto svakodnevno konzumira ove napitke. ${ }^{38}$ Jedna trećina Australaca konzumira prosječno otprilike jednu limenku SSB-a na dan, što ih svrstava među deset najvećih potrošača ovih napitaka u svijetu. U Meksiku, četvrtoj zemlji na svijetu po konzumaciji SSB-a (163 litre na godinu po stanovniku) i zemlji s više od 70 posto preuhranjene i pretile odrasle populacije, čak 71 posto dodanog šećera stanovništvo unosi kroz SSB-e. ${ }^{39}$ Sjedinjene Države, Kina i Indija, zemlje s najvećim brojem pretilih osoba na svijetu, pripadaju i u skupinu deset najvećih tržišta prema ukupnoj potrošnji SSB-a. U istu skupinu ulaze i Meksiko, Brazil, Njemačka, Argentina, Velika Britanija, Japan i Filipini, zemlje s natprosječnim dnevnim unosom kalorija i/ili stopama prevalencije pretilosti (izuzetak je Japan). ${ }^{40}$

Suočene s visokim stopama prevalencije pretilosti i pratećih bolesti, velikom potrošnjom SSB-a i rastućim zdravstvenim troškovima, trideset i pet zemalja širom svijeta, ${ }^{41}$ kao i brojne regije i gradovi, uveli su u svoje porezne sustave trošarine na SSB-e. Trošarinama se ovi napitci oporezuju u Mađarskoj (od 2011. g.), Francuskoj (od 2012.), Meksiku (od 2014.), Čileu (od

34 Sweet Act, op. cit. u bilj. 7.

35 Singh, G. M.; Micha, R.; Khatibzadeh, S. et al., Estimated Global, Regional and National Disease Burdens Related to Sugar-Sweetened Beverage Consumption in 2010, https://www.ncbi.nlm.nih.gov/pubmed/26124185, pristupljeno 20. travnja 2017.

36 Sweet Act, op. cit. u bilj. 7.

37 Brownell, K. D. et al., op. cit. u bilj. 29, str. 2. Novija istraživanja ukazuju kako iznimno malih 2,7 posto Amerikanaca vodi zdrav život, no struktura njihove prehrane ipak se poboljšava. Od 1990-ih do 2012. g. potrošnja na organsku hranu u Sjedinjenim Državama povećana je 20 puta, premda to i dalje čini malih 4 posto ukupne nacionalne potrošnje na hranu. The Economist, Bitter Fruits Dietary Inequality, August 13, 2016., str. 31. i Schlosser, E., Still a Fast Food Nation: Eric Schlosser Reflects on 10 Years Later, 2012., http://www.thedailybeast.com/still-a-fast-food-nation-eric-schlosser-reflects-on-10-years-later, pristupljeno 2. kolovoza 2017.

38 University of Sydney, op. cit. u bilj. 12. Prema petnaestom po redu dvogodišnjem zdravstvenom izvješću Australian Institute of Health and Welfare, polovica stanovnika Australije živi s jednom ili više kroničnih bolesti, 1,2 milijuna stanovnika ima dijabetes, od kojih 85 posto ima dijabetes tipa 2. Davey, M., Australia should introduce 40 cent sugar tax on sweetened drinks - Grattan report, https://www.theguardian.com/australia-news/2016/nov/22/australia-should-introduce-40-sugar-tax-on-sweetened-drinksgrattan-report, pristupljeno 10. svibnja 2017.

39 U Meksiku 34 posto djece između 5 i 11 godina ima prekomjernu tjelesnu masu, a 12 posto stanovništva je oboljelo od dijabetesa. The Economist, Taxing sugary drinks - Stopping slurping, http://www.economist.com/news/finance-and-economics/21679259-taxesfizzy-drinks-seem-work-intended-stopping-slurping, pristupljeno 20. svibnja 2017. globalhealth.thelancet.com/2016/06/10/growth-rates-and-aggregates-bringing-data-soda-wars, pristupljeno 21. travnja 2018. 
2014.), Ujedinjenim Arapskim Emiratima (od 2017.), Irskoj, Velikoj Britaniji, Norveškoj i Južnoj Africi (u svima od 2018. g.) itd. U Sjedinjenim Državama trošarina na SSB-e nije uvedena na saveznoj razini, ali je sedam gradova uvelo svoje lokalne poreze: Berkeley, Philadelphia, San Francisco, Oakland, Albany, Seattle i Boulder. Iznosi trošarina variraju u zavisnosti od poreznog područja, a pri utvrđivanju iznosa trošarina porezne vlasti u obzir uzimaju prosječne prihode poreznih obveznika, zacrtane javnozdravstvene ciljeve i političke okolnosti. U američkim gradovima prosječna trošarina iznosi 1 - 2 centa po unci napitka (oko $30 \mathrm{ml}$ ), što je ekvivalent 5 postotnom povećanju cijene SSB-a. U Francuskoj trošarina iznosi 7,16 eura po hektolitru (ekvivalent je oko 6 postotno povećanje cijene SSB-a), a u Irskoj 30 centi po litri napitka koji sadrži više od 8 grama šećera na $100 \mathrm{ml}$. U Meksiku trošarina iznosi 1 pesos po litri (otprilike 10 postotno povećanje prosječne cijene SSB-a), a u Velikoj Britaniji 18 penija po litri napitka koji sadrži pet ili više grama šećera na $100 \mathrm{ml}$, odnosno 24 penija po litri za napitke koji sadrže osam ili više grama šećera na 100 ml. U Južnoj Africi trošarina iznosi 2,1 cent po gramu dodanog šećera iznad razine od 4 grama na 100 ml napitka. U Čileu iznos trošarine utječe na otprilike 5 postotno povećanje cijene prosječnog pakiranja SSB-a. Nakon uvođenja trošarina cijene SSB-a u prosjeku su porasle između pet i deset posto.

Uvođenju trošarina na SSB-e najsnažnije se odupiru proizvođači napitaka i njihova poslovna udruženja, zaposleni u proizvodnji SSB-a, trgovački lanci i mali trgovci itd., ali i gorljivi zagovornici politike slobodnih tržišta i minimalne države. Suprotstavljanje trošarinama opravdavaju cjenovno neelastičnom potrošnjom SSB-a, kao i regresivnim djelovanjem koje najteže pogađa najsiromašnije potrošače. Ističe se i kako trošarine ukidaju radna mjesta kod proizvođača i trgovaca, kao i da predstavljaju nedopustivo miješanje u slobodu izbora potrošača i djelovanje tržišnih zakonitosti. Loša strana im je i to što potrošače pritjeruju na krijumčarenje ili prekograničnu kupnju jeftinijih SSB-a. Zbog navedenih razloga trošarine su s aspekta javnozdravstvenih i drugih ciljeva neučinkovite i nepravedne, a priželjkivani učinci mogu se brže postići kroz dragovoljne promjene kod proizvođača, npr. razvojem novih napitaka sa smanjenim udjelom šećera, ali i zabranom reklamiranja i prodaje SSB-a u školama, vidljivim označavanjem zdravstvenog rizika na pojedinim proizvodima, informativno-edukativnim kampanjama o zdravoj prehrani, podupiranjem fizičkih aktivnosti stanovništva itd. ${ }^{42}$

Pobornici uvođenja trošarina kritike odbacuju i nude teorijski i činjenično obrazložene protuargumente. Iako cjenovna elastičnost potrošnje odista može varirati u zavisnosti od npr. lokacije ili socioekonomskog statusa osobe, elastičnost potrošnje SSB-a procijenjena je na -0,7 do -0,9. To znači da potražnja slabi za 7 do 9 posto na svakih deset posto porasta cijene, a najelastičnija je kod osoba s nižim socioekonomskim statusom. Postojanje elastičnosti potvrđuje analiza vladina National Institute for Public Health prema kojoj je prodaja SSB-a u Meksiku u prvoj godini nakon uvođenja trošarina smanjena za 5,5 posto, a 9,7 posto u 2015. g. ${ }^{43}$ Rezultati

42 Na poziv Public Health England, vladina savjetodavna tijela za javnozdravstvenu politiku u cijeloj Britaniji, proizvođači hrane bi u razdoblju od 2016. do 2020. trebali dragovoljno smanjiti udio šećera u deset kategorija hrane (uz smanjenje veličine pakiranja). Ovaj program je dio vladinih aktivnosti na smanjivanju dječje pretilosti, a najbolje rezultate zasad su postigli proizvođači SSB-a smanjivši udio šećera za 11 posto na $100 \mathrm{ml}$ napitka. Udruženje proizvođača hrane je pozvalo da se smanjivanjem porcija u program uključe i restorani i barovi koji poslužuju hranu, zato što prosječni Britanci izvan svojih domova unesu 25 posto ukupne dnevne količine kalorija. Na hranu i napitke koje su kupili i konzumirali izvan kuće Britanci su 2017. g. potrošili 56 milijardi eura. Niamh, M., British food firms fail on government's 5\% sugar reduction target, 2018., https://www.foodnavigator.com/ Article/2018/05/22/British-food-firms-fail-on-government-s-5-sugar-reduction-target, pristupljeno 24. svibnja 2018.

43 Macguill, D., FastCheck: Do Taxes on Sugary Drinks Actually Work?, thejournal.ie, http://www.thejournal.ie/sugar-soft-drinks-taxdoes-it-work-health-benefits-facts-2918363-Oct2017/, pristupljeno 15. travnja 2018. 
istraživanja potvrđuju kako je pad potražnje zabilježen u svim socioekonomskim skupinama, a najsnažnije u skupini s niskim socioekonomskim statusom ${ }^{44}$ i visokim stopama pobola od pretilosti i dijabetesa tipa $2 .{ }^{45}$ Nalazi opservacijske studije sugeriraju postupno odvikavanje stanovništva od konzumacije SSB-a, dok se istodobno povećava potrošnja tzv. flaširane vode (4 posto u 2014. g.). Dugoročno se, dakle, mogu očekivati sve značajniji učinci trošarina, što bi u idućih deset godina trebalo spriječiti razvoj oko 190.000 novih slučajeva dijabetesa i dovesti do uštede od 785 milijuna eura na zdravstvenim troškovima. ${ }^{46}$ Podaci za grad Berkeley također potvrđuju da je u dvije godine primjene trošarina (i snažne zdravstvene kampanje o štetnosti SSB-a) prodaja SSB-a smanjena za 10 posto. Čile također bilježi pad potrošnje SSB-a, ali i smanjivanje stope prevalencije pretilosti za 0,99-2,4 posto. ${ }^{47} \mathrm{Pad}$ prodaje SSB-a potvrđen je i u Francuskoj, a prosječno iznosi 3 - 3,5 litre SSB-a po stanovniku na godinu. ${ }^{48} \mathrm{U}$ Mađarskoj je u razdoblju 2011. - 2013. g. prodaja zaslađenih napitaka smanjena za 15,1 posto, ali je pad prodaje od 13,5 posto zabilježen i u razdoblju prije uvođenja trošarina (2007. - 2011. g.). ${ }^{49}$

Ipak, stvarna potrošnja SSB-a može slabije reagirati na rast cijena ako proizvođači/trgovci iznos trošarina apsorbiraju i ostave cijene SSB-a nepromijenjenima te kada potrošači prihvate porast cijena ili pronađu neoporezovane i jeftinije zamjenske proizvode. U ovim slučajevima trošarine znatno manje utječu na pad potrošnje SSB-a, kao i na smanjivanje energetskog unosa i prevalencije pretilosti..$^{50}$

Nadalje, trošarine na SSB-e nisu nepravedne prema najsiromašnijima, premda upravo njih financijski relativno najviše pogađaju. Njima trošarine zapravo najviše koriste - smanjujući potrošnju SSB-a, raste im raspoloživi dohodak, a trošeći zdravije napitke (npr. vodu) jačaju zdravlje, smanjuju zdravstvene izdatke i povećavaju radne aktivnosti. S obzirom na to da u apsolutnim

44 Colchero, M. A., Popkin, B. M. et al., Beverage Purchases From Stores in Mexico Under the Excise Tax on Sugar Sweetened Beverages: Observational Study, British Medical Journal, 352, h6704, 2016., https://www. bmj. com/ content/352/bmj.h6704, pristupljeno 29. ožujka 2018.

45 The Lancet Diabetes and Endocrinology. Editorial, Sweet Success: Will Sugar Taxes Improve Health?, god. 5, br. 4, $2017 .$, str. 235. U skupini s višim socioekonomskim statusom kupnja zaslađenih napitaka nakon uvođenja trošarina nije statistički znatnije smanjena, dok je u skupini s nižim socioekonomskim statusom kupnja smanjena za 17 posto. Gunn, L., Are Sin Taxes Good for Public Health? Lancet Analysis Suggests Benefit for Soft Drinks Levy, Nutrition Insight, 2018., http://www.nutritioninsight.com/ news/taxes-on-soft-drinks-alcohol-and-tobacco-powerful-tools-to-combat-rising-rates-of-chronic-diseases-the-lancet.html, pristupljeno 5. svibnja 2018. Na prigovor da je ukupan pad potrošnje SSB-a slab, odgovor je da je u dvije godine pad potrošnje SSB-a per capita u Meksiku veći nego što je ukupna prosječna potrošnja SSB-a per capita u Indiji. Cherukupallli, R., op. cit. note 40.

46 Uz uštede na zdravstvenim troškovima, tijekom prve dvije godine implementacije trošarina Meksiko je prikupio 2,6 milijardi dolara poreznih prihoda i dio usmjerio u opskrbu škola pitkom tekućom vodom. The Lancet Diabetes and Endocrinology, op. cit. note 45. Projekcija izrađena za Britaniju govori da bi postupno smanjenje udjela dodanog šećera za 40 posto u zaslađenim napitcima u idućih pet godina smanjilo broj pretilih odraslih osoba za pola milijuna i spriječilo pojavu 300.000 novih oboljenja od dijabetesa. Za Irsku se uz iznos trošarine od 10 posto na cijenu SSB-a i elastičnost potrošnje od 0,9 predviđa smanjenje prevalencije pretilosti za 1,25 posto među odraslom populacijom. Department of Health Working Paper - Ireland, Introducing A Tax On Sugar Sweetened Drinks - Health Rationale, Options and Recommendations, 2016., https://health.gov.ie/wp-content/ uploads/2016/10/INTRODUCING-A-TAX-ON-SUGAR-SWEETENED-DRINKS-FINA.pdf, pristupljeno 20. siječnja 2018.

Bascuñán, J., Cuadrado, C., Effectiveness of Sugar-sweetened Bevarages Taxes to Reduce Obesity: Evidence Brief for Policy, author information, 2017, https://www.ncbi.nim.nih.gov/pubmed/29099817, pristupljeno 30. travnja 2018.

48 Scarborough, P., Briggs, A., The Insitute of Fiscal Studie's verdict on a sugary drink tax, The Lancet, god. 387, br. 10024, 2016., str. 1162.

Macguill, D., op. cit. note 43.

$50 \quad$ Ibidem. Na čimbenike koji smanjuju elastičnost potrošnje SSB-a istraživači često upozoravaju. Vidi više Zhen, C., Finkelstein, E.A. et al., Predicting effects of sugar-sweetened beverage taxes on food and beverage demand in a large demand system, American Journal of Agricultural Economics, 2013. i Duke Global Helath Institute and Duke-National University of Singapore (NUS), Soda Tax May Only Lead to Modest Weight Loss, 2010. 
iznosima troše više na SSB-e od siromašnijih osoba, državnoj blagajni će najviše pridonositi osobe visokog socioekonomskog statusa. Usmjere li se prihodi od trošarina na programe prevencije i kontrole pretilosti, zdravstvenu skrb siromašnih, poboljšanje prehrane djece, mladih i depriviranih itd., najviše koristi imat će oni koje pretilost i prateće bolesti češće i teže pogađaju.

Trošarine ne smanjuju broj zaposlenih u prehrambenoj industriji i trgovini, barem ne $u$ mjeri koju ističu u ovim gospodarskim sektorima. Uz to, potrošači ne prestaju kupovati bezalkoholne napitke, već potražnju preusmjeravaju prema nutritivno kvalitetnijim i neoporezovanim napitcima. Stoga se u proizvodnji napitaka sa smanjenim udjelima šećera ili potpuno novih napitaka zadržavaju postojeća ili otvaraju nova radna mjesta. ${ }^{51}$

Uvođenje trošarina na SSB-e odista znači upletanje države u slobodu izbora potrošača i djelovanje tržišnih zakonitosti, ali to i jest njezina zadaća u slučajevima nastanka negativnih eksternalija kao posljedica proizvodnje ili potrošnje zdravstveno i ekološki štetnih proizvoda (cigarete, alkohol, azbestne ploče, goriva itd.). Uz to, društvo mora iznaći sredstva za saniranje značajnih troškova kao posljedica negativnih izvanjskih učinaka.

Iako se ukidanje trošarina na SSB-e 2014. g. u Danskoj može donekle obrazložiti njihovom neučinkovitošću uzrokovanom kupnjom jeftinijeg SSB-a u Švedskoj i Njemačkoj, pretjerane su tvrdnje da će zbog razlika u iznosima trošarina između pojedinih zemalja znatno porasti krijumčarenje i prekogranična kupnja jeftinijeg SSB-a. No rješenje je za nedopuštenu trgovinu u harmoniziranju stopa trošarina na SSB-e i zajedničkom definiranju proizvoda, osnovica i izuzeća oporezivanja između više poreznih područja (pogotovo unutar EU-a i sličnih asocijacija), kao i u izgradnji širokog nadnacionalnog informacijskog sustava i sustava suradnje carinskih i poreznih službi. ${ }^{52}$ Rezimirajući argumente pro et contra trošarina i analizirajući rezultate dosad provedenih analiza učinaka trošarina na smanjenje potrošnje SSB-a i prevalencije pretilosti, može se izvesti nekoliko zaključaka. Kao prvo, više istraživanja je potvrdilo da trošarine utječu na smanjivanje prodaje i potrošnje SSB-a, najviše među populacijom s niskim socioekonomskim statusom. Trošarine utječu ne samo na pad potrošnje SSB-a, nego i na rast potrošnje nutritivno kvalitetnijih napitaka (npr. vode). Drugo, sve je više dokaza da pad potrošnje SSB-a i rast potražnje za nutritivno kvalitetnijim napitcima utječu na smanjenje unosa kalorija, prosječnog ITM-a i prevalenciju pretilosti. Iako malobrojna, već postoje istraživanja čiji rezultati potvrđuju smanjeni unos kalorija i prosječnog ITM-a kod pretile djece i osoba s niskim socioekonomskim statusom. Buduća istraživanja vjerojatno će utvrditi kako na duži rok trošarine snažnije djeluju na smanjenje prosječnog ITM-a i prevalenciju pretilosti. Trošarine nemaju značajniji učinak na one koji umjereno konzumiraju SSB-e, ali smanjenje kalorijskog unosa i za npr. 1 do 2 posto na godinu na razini ukupne populacije dovodi do smanjivanja prosječnog ITM-a i prevalencije pretilosti. Treće, zbog toga što su iznosi trošarina najčešće preniski da bi u većoj mjeri utjecali na smanjenje potrošnje, iznose trošarina na SSB-e treba povećati. Procjene sugeriraju da bi rast cijena SSB-a za oko 20 posto značajno smanjio prosječan unos kalorija, ITM-e i stope prevalencije pretilosti. Učinci trošarina na prevenciju pretilosti (i njihovo prihvaćanje od strane javnosti) rastu ako njihovu primjenu prate široke javnozdravstvene i obra-

51 The Nutrition Health Alliance, Uncapping the Truth: The Mexican Sugar Sweetened Beverage Tax Works, 2016., https://www. sidint.net/sites/www.sidint.net/files/Fact\%20sheetUncapping\%20the\%20truth\%20Mexico\%20SSB\%20tax-June2016.pdf, pristupljeno 4. kolovoza 2017.

52 Kuliš, D., Oporezivanje potrošnje: porez na dodanu vrijednost i trošarine, Newsletter, povremeno glasilo Instituta za javne financije, 33/2007., http://www.ijf.hr/newsletter/33.pdf, pristupljeno 14. svibnja 2017., str. 6.-8. 
zovne kampanje o štetnom utjecaju SSB-a na zdravlje populacije. Četvrto, efikasnost trošarina smanjuje se ako potrošači mogu jednostavno pronaći i kupovati neoporezovane napitke s visokim energetskim udjelom, kupovati jeftiniji SSB-e u susjednim zemljama ili ako proizvođači/distributeri većim dijelom apsorbiraju iznose trošarina..$^{53}$ Peto, trošarine na SSB-e izdašan su izvor poreznih prihoda koji se mogu iskoristiti za financiranje raznorodnih aktivnosti na prevenciji i kontroli pretilosti, što smanjuje potrebu za drugim oblicima oporezivanja. Šesto, trošarine imaju neznatan negativan utjecaj na profitabilnost proizvođača SSB-a, a zahvaljujući diversifikaciji proizvoda i na ukupan broj zaposlenih u proizvodnji bezalkoholnih napitaka. Trošarine stimuliraju proizvođače SSB-a (ali i drugih segmenata prehrane) na promjene u recepturi i smanjivanje udjela šećera u proizvodima.

Premda se SSB-i u Hrvatskoj oporezuju trošarinama, iznosi trošarina su niski i nemaju utjecaj na smanjivanje potrošnje SSB-a, unos kalorija i prevenciju pretilosti. ${ }^{54}$ Zbog visokih stopa prevalencije pretilosti i rastućih zdravstvenih troškova povezanih s posljedicama pretilosti (npr. dijabetes!) trošarine na zaslađena bezalkoholna pića u Hrvatskoj treba postupno povećavati, sve do razine poreznog opterećenja koja će se kroz iskustva iz drugih poreznih sustava pokazati efikasnom u prevenciji i kontroli pretilosti.

S obzirom na kratko vrijeme primjene trošarina o njihovim javnozdravstvenim i drugim učincima nužno je provoditi kontinuirana medicinska, ekonomska i druga istraživanja financirana iz javnih izvora. ${ }^{55} \mathrm{Uz}$ uvođenje trošarina na SSB-e, sve veću pozornost šire javnosti zaokupljaju i prijedlozi za oporezivanje drugih segmenata prehrane s visokim i za zdravlje štetnim udjelima zasićenih masti (fat-tax), šećera (sugar-tax) i soli (salt-tax).

\section{ZAKLJUČNA RAZMATRANJA}

Od pretilosti globalno već boluje više od 600 milijuna odraslih osoba i djece. Uz narušeno zdravlje, oboljeli imaju teške financijsko-ekonomske i socijalne probleme, a društvo s uspo-

53 O zaključcima ovdje iznesenim šire u istraživanjima: Finkelstein, E. A., Chen, Z. et al., Impact of Targeted Beverage Taxes on Higher and Lower-Income Households, Arch Intern Med., Vol. 170, No. 22, 2010., str. 2028-2034; Andreyeva, T.; Chaloupka, F. J.; Brownell, K. D., Estimating the Potential of Taxes on Sugar-Sweetened Beverages to Reduce Consumption and Generate Revenue, Preventive Medicine, god. 52, br. 6, 1 June 2011., str. 413.-441; Wang, Y. C., Coxson, P. et al., A Penny-Per-Ounce Tax On Sugar-Sweetened Beverages Would Cut Health And Cost Burdens Of Diabetes, Health Affairs, god. 31, br. 1, 2012. Na mrežnoj stranici University of Wisconsin, Population Health Institute and School of Medicine and Public Health, What works for Health - Sugar Sweetend Beverage Taxes, 2017., http://whatworks forhealth.wisc.edu/program.php?t1=21\&t2=12\&t3=73\&id=505, nalazi se opsežan popis provedenih istraživanja (za razdoblje od 2005. do 2017. godina) o učincima trošarina na ukupnu i potrošnju SSB-a prema socioekonomskim skupinama, unos kalorija, stanje ITM-a, prevalenciju pretilosti, fiskalne prihode države i drugu s trošarinama povezanu problematiku.

54 Zakon o posebnom porezu na kavu i bezalkoholna pića, Narodne novine, broj 72/2013, čl. 3. i 4. Zavisno od vrste napitka trošarine iznose $40 \mathrm{kn}$ po hektolitru vode, uključujući mineralne vode i gazirane vode, s dodanim šećerom ili drugim sladilima ili aromatizirane te ostala bezalkoholna pića iz tarifne oznake KN 2202 (osim voćnih sokova i voćnih nektara), 240 kn po hektolitru sirupa i koncentrata namijenjenih za pripremu bezalkoholnih pića, te $400 \mathrm{kn}$ po $100 \mathrm{~kg}$ neto mase prašaka i granula namijenjenih za pripremu bezalkoholnih pića. Voćni sokovi, voćni sirupi i sirupi od povrća su izuzeti od oporezivanja. Premda su nakon poreza na dodanu vrijednost trošarine drugi najveći izvor prihoda državnog proračuna (oko 14 mlrd. kuna u 2016. g.), u strukturi ukupnih prikupljenih prihoda od posebnih poreza trošarine na bezalkoholna pića sudjeluju s oko 1 posto.

55 Posebna istraživanja utvrdila su kako studije o učincima trošarina na SSB-e financirana od strane prehrambene industrije imaju znatne metodološke nedostatke (u prikupljanju, analizi, tumačenju i/ili objavljivanju podataka), a zaključci o nepostojanju negativnog utjecaja prekomjerne potrošnje SSB-a na zdravlje su četiri do osam puta češći nego kod nezavisnih akademskih istraživanja. Macguill, D., op. cit. note 43. 
renim ekonomskim rastom i financiranjem rastućih zdravstvenih troškova povezanih s debljinom i pratećim bolestima. Postojeći trendovi ukazuju na realnu mogućnost da u idućih desetak godina čak petina odraslog stanovništva na svijetu oboli od ove bolesti. Temeljni je uzrok razvoja pretilosti poremećena ravnoteža između unosa kalorija i njihove potrošnje, no raznorodni čimbenici i njihova kompleksna međudjelovanja dovode do nastanka neravnoteže. Najutjecajniji čimbenici su socioekonomski, tj. niski socioekonomski i/ili obrazovni status (koji sužavaju nutricionistički suverenitet potrošača) i bihevioristički (loše prehrambene navike, sjedilački način života itd.), no pretilost se može razviti i kao posljedica djelovanja bioloških, genetskih, ekoloških, psiholoških i farmakoloških čimbenika rizika.

Suočene s velikom potrošnjom SSB-a, visokim stopama prevalencije pretilosti i rastućim zdravstvenim troškovima povezanim s debljinom, sve veći broj zemalja, ali i regija i gradova, u svoje porezne sustave uveo je trošarine na SSB-e. Trošarine su kao poseban oblik poreza na promet koristan instrument ostvarivanja javnozdravstvenih ciljeva, u ovom slučaju prevencije i kontrole pretilosti. Javnozdravstvena logika uvođenja trošarina na SSB-e oslanja se na pad potrošnje kao posljedice rasta cijena ovih napitaka, smanjivanje unosa kalorija i stopa prevalencije pretilosti. Uvođenjem trošarina na SSB-e država se, kao i kod drugih društveno nepoželjnih proizvoda, upleće u izbor potrošača i potiče ih na kvalitativne promjene u strukturi prehrane i povećanu brigu za vlastito zdravlje. Obavljena istraživanja pokazuju da su trošarine na SSB-e najučinkovitije u prevenciji i kontroli pretilosti kod djece, mladih i osoba s nižim socioekonomskim statusom, ionako najrizičnijim skupinama u pogledu oboljenja od pretilosti.

Trošarine su izdašni porez koji značajno pridonosi poreznim prihodima države iz kojih se mogu pojačano financirati raznorodne aktivnosti na prevenciji i liječenju pretilosti i komorbiditeta. Prikupljeni porezni prihodi mogu se također upotrijebiti za subvencioniranje prehrane i zdravstvene skrbi djece i siromašnih obitelji, ali i proizvodnju nutritivno kvalitetnijih poljoprivredno-prehrambenih proizvoda. Suočeni s vjerojatnim padom potrošnje SSB-a, trošarine proizvođače potiču na proizvodnju napitaka (i drugih segmenata prehrane) sa smanjenim udjelima dodanih šećera. Uz pozitivne javnozdravstvene i fiskalne učinke, trošarine ne stvaraju značajnije ekonomske poremećaje kod proizvođača i distributera bezalkoholnih napitaka, niti dovode do ukidanja radnih mjesta. U slučaju viših iznosa trošarina i znatnijeg porasta prodajnih cijena SSB-a (koji neće apsorbirati proizvođači ili distributeri) pozitivni učinci trošarina bili bi izraženiji, kao i kada potrošači ne bi imali lak pristup neoporezovanim alternativnim napitcima s visokim udjelima šećera.

Uvođenje i primjenu trošarina na SSB-e prate snažne kritike i protivljenja, najžešća iz redova proizvođača i distributera SSB-a, no rezultati provedenih empirijskih istraživanja pokazuju da su trošarine u pogledu smanjenja potrošnje SSB-a i prevalencije pretilosti učinkovit instrument ostvarivanja javnozdravstvenih, ali i fiskalnih i socijalnih ciljeva povezanih s debljinom i pratećim bolestima. Pozitivan učinak trošarina na ostvarivanje zacrtanih ciljeva rast će s produljenim razdobljem njihove primjene. Učinke bi povećalo i pažljivo harmoniziranje iznosa trošarina na SSB-e u većem broju poreznih područja (npr. na razini EU-a), što pak zahtijeva i izradu zajedničke javnozdravstvene politike.

Zbog kratkog razdoblja primjene, nedvojbeni zaključci oko doprinosa trošarina na SSB-e prevenciji i kontroli pretilosti mogu se očekivati tek u idućim godinama. Ipak, žustre javnozdravstvene, političke i ekonomske debate oko njihove učinkovitosti i pravednosti usmjerili su pozornost globalne javnosti na problematiku oko pretilosti i osnažile podršku zagovornici- 
ma oporezivanja SSB-a i drugih segmenata prehrane štetnih za zdravlje. Budući da kod nastanka i prevalencije pretilosti prevladavaju socioekonomski i bihevioralni razlozi a ne medicinski, uspješne aktivnosti na prevenciji i kontroli pretilosti trebaju se temeljiti na uravnoteženom, međusobno usuglašenom i kontinuiranom sklopu javnozdravstvenih, fiskalnih, ekonomskih, socijalnih, edukativnih, kulturalnih, prostorno-građevinskih, regulativnih i drugih javnih mjera i politika. Iako se pretilost može spriječiti, nažalost ne postoji skup preventivnih planova i mjera aktivnosti koji bi brzo zaustavio rast prevalencije pretilosti. To se ne može očekivati niti od trošarina na SSB-e, pogotovo ako njihovo uvođenje i primjena ostane usamljeni napor društva u borbi protiv pretilosti, pogoršanja zdravlja i kvalitete života stanovništva.

\section{LITERATURA}

\section{A) KNJIGE I ČLANCI}

1. Bobinac, Ana, Zdravlje je neprocjenjivo, zdravstvo ima cijenu. Znamo li ju izračunati?, Jutarnji list, 24. lipnja 2017.

2. Brownell, K. D.; Farley, T.; Willet, W. C. et al., The Public Health and Economic Benefits of Taxing Sugar-Sweetened Beverages, The New England Journal of Medicine, god. 361, br. 16, 2009., str. 1599.-1605.

3. Dobbs, R.; Sawers, C.; Thompson, F. et al., Overcoming Obesity: An Initial Economic Analysis, discussion paper, McKinsey Global Institute, London- San Francisco-Shanghai, 2014, str. 1.-106.

4. Drewnowski, A., Fat and Sugar: An Economic Analysis, The Journal of Nutrition, god. 133, br. 3, 2003., str. 838.-840.

5. Drewnowski, A., Obesity, Diets, and Social Inequalities, Nutrition Reviews, god. 67 (Suppl 1), 2009., str. 536.-539.

6. Đorđević, V., Braš, M., Psihološki aspekti barijatrijske kirurgije, u: Bekavac-Bešlin, M., Pašić, F., et al. (ur.) Kirurško liječenje bolesti debljine, Zagrebački institut za kulturu zdravlja, Zagreb - Tuzla, 2017., str. 173.-180.

7. Harari, Y. N., Sapiens - kratka povijest čovječanstva, Fokus komunikacije, Zagreb, 2015.

8. Musić Milanović, S., Delaš, M., Debljina i čimbenici rizika, u: Bekavac-Bešlin, M., Pašić, F. et al. (ur.) Kirurško liječenje bolesti debljine, Zagrebački institut za kulturu zdravlja, Zagreb - Tuzla, 2017., str. 163.-172

9. Sassi, F.; Belloni, A.; Mirelman, A. J., Equity Impacts of Price Policies to Promote Healthy Behaviours, The Lancet, god. 391, br. 10134, 2018., str. 2059.-2070.

10. Scarborough, P., Briggs, A., The Institute of Fiscal Studie's verdict on a sugary drink tax, The Lancet, god. 387, br. 10024, 2016., str. 1162.

11. Smolić, Š., Zdravstveni sustav, u: Obadić, A., Tica J. (ur.) Gospodarstvo Hrvatske, Ekonomski fakultet u Zagrebu, Zagreb, 2016., str. 471.-508.

12. Šimurina, N.; Dražić Lutilsky, I.; Barbić, D.; Dragija Kostić, M., Osnove porezne pismenosti, Ekonomska biblioteka, Narodne novine, Zagreb, 2018., str. 97.-100.

13. The Economist, Bitter Fruits - Dietary Inequality, August 13, 2016., str. 31.

14. The Lancet Diabetes and Endocrinology. Editorial, Sweet Success: Will Sugar Taxes Improve Health?, god. 5, br. 4, 2017., str. 235. 
15. Toromanović, A., Liječenje pretilosti adolescenata, u: Bekavac-Bešlin, M., Pašić, F. i suradnici, (ur.) Kirurško liječenje bolesti debljine, Zagrebački institut za kulturu zdravlja, Zagreb - Tuzla, 2017., str. 181.-201.

\section{B) MREŽNI IZVORI}

1. Bascuñán, J., Cuadrado, C., Effectiveness of Sugar-sweetened Bevarages Taxes to Reduce Obesity: Evidence Brieffor Policy, author information, 2017, https://www.ncbi.nim.nih.gov/pubmed/29099817, pristupljeno 30. travnja 2018.

2. Boseley, S(ed.) Mexico's Sugar Tax Leads to Fall in Consumption for Second Year Running, www.theguardian.com/society/2017/feb/22/mexico-sugar-tax-lower-consumption-second-year-running, pristupljeno 9. svibnja 2017.

3. Centers for Desease and Prevention - Morbidity and Mortality Weekly Report, Trends in Intake of Energy and Macronutritients - United States, 1971-2000, https://www.cdc.gov/mmwr/preview/ mmwrhtml/mm5304a3.htm, 2004., pristupljeno 24. srpnja 2017.

4. Cherukupalli, R., Growth rates and aggregates: bringing data to the soda wars, The Lancet global health blog, 2016., http://globalhealth.thelancet.com/2016/06/10/growth-rates-and-aggregatesbringing-data-soda-wars, pristupljeno 21. travnja 2018.

5. Colchero, M.A., Popkin, B.M. et al., Beverage purchases from stores in Mexico under the excise tax on sugar sweetened beverages: observational study, British Medical Journal 2016;352:h6704, https:// www.bmj.com/content/352/bmj.h6704, pristupljeno 29. ožujka 2018.

6. Davey, Melissa, Australia should introduce 40 cent sugar tax on sweetened drinks - Grattan report, https://www.theguardian.com/australia-news/2016/nov/22/australia-should-introduce-40-sugar-tax-on-sweetened-drinks-grattan-report, pristupljeno 10. svibnja 2017.

7. Department of Health Working Paper - Ireland, Introducing A Tax On Sugar Sweetened Drinks Health Rationale, Options and Recommendations, 2016., https://health.gov.ie/wp-content/uploads/2016/10/INTRODUCING-A-TAX-ON-SUGAR-SWEETENED-DRINKS-FINA.pdf, pristupljeno 20. siječnja 2018.

8. Finkelstein, E. A., Chen, Z. et al., Impact of Targeted Beverage Taxes on Higher- and Lower-Income Households, 2010, https://jamanetwork.com/journals/jamainternalmedicine/fullarticle /776479?link=xref, pristupljeno 4. travnja 2018.

9. Fox, M., America's Obesity Epidemic Hits a New High, NBC News, 2016, https://www.nbcnews.com/ health/health-news/america-s-obesity-epidemic-hits-new-high-n587251, pristupljeno 21. srpnja 2017.

10. Goozner, M., Unchecked Obesity Rates Could Bankrupt Nation, The Fiscal Times, 2012., http://www. thefiscaltimes.com/Articles/2012/09/19/Unchecked-Obesity-Rates-Could-Bankrupt-Nation, pristupljeno 5. srpnja 2017.

11. Gunn, L., Are Sin Taxes Good for Public Health? Lancet Analysis Suggests Benefit for Soft Drinks Levy, Nutrition insight, 2018., http://www.nutritioninsight.com/news/taxes-on-soft-drinks-alcohol-andtobacco-powerful-tools-to-combat-rising-rates-of-chronic-diseases-the-lancet.html, pristupljeno 5. svibnja 2018.

12. Healthy Food America, Taxing Sugary Drinks, http://www.healthyfood america.org/taxing sugary-drinks, pristupljeno 5. svibnja 2018. 
13. IHME - Institute for Health Metrics and Evaluation, Nearly one-third of the World's Population is Obese or Overweight, New Data Show, http://www.healthdata.org/newsrelease/nearly-one-third-world's-population-obese-or-overweight-new-data-show, pristupljeno 20. srpnja 2017.

14. Kuliš, D., Oporezivanje potrošnje: porez na dodanu vrijednost i trošarine, Newsletter, povremeno glasilo Instituta za javne financije, 33/2007., http://www.ijf.hr/newsletter/33.pdf, pristupljeno 14. svibnja 2017., str. 6.-8.

15. Macguill, D., FastCheck: Do Taxes on Sugary Drinks Actually Work?, thejournal.ie, http://www.thejournal.ie/sugar-soft-drinks-tax-does-it-work-health-benefits-facts-2918363-Oct2017/, pristupljeno 15. travnja 2018.

16. National Health Service (England), Global obesity rates expected to soar in next decade, www.nhs.uk/ news/2016/04April/Pages/Global-obesity-rates-expected-to-soar-in-next-decade.aspx, pristupljeno 20. veljače 2017.

17. Niamh, M., British Food Firms Fail on Government's 5\% Sugar Reduction Target, 2018., https://www. foodnavigator.com/Article/2018/05/22/British-food-firms-fail-on-government-s-5-sugar-reduction-target, pristupljeno 24. svibnja 2018.

18. Peppers, M., Daily Calorie Intake of Coutries Across the World Eevealed... and (surprise) the U. S. Tops the List at 3.770., Mailonline, http://www.dailymail.co.uk/femail/article-2722815/Daily-calorie-intake-countries-world-revealed-surprise-U-S-tops-list-3-770.html., 2014., pristupljeno 18. srpnja 2017.

19. Singh, G. M.; Micha, R.; Khatibzadeh, S. et al., Estimated Global, Regional and National Disease Burdens Related to Sugar-Sweetened Beverage Consumption in 2010, https://www.ncbi.nlm.nih.gov/pubmed/26124185, pristupljeno 20. travnja 2017.

20. Schlosser, E., Still a Fast Food Nation: Eric Schlosser Reflects on 10 Years Later, 2012., http://www. thedailybeast.com/still-a-fast-food-nation-eric-schlosser-reflects-on-10-years-later, pristupljeno 2. kolovoza 2017.

21. Sweet Act, Sugar-Sweetened Beverages Tax Act of 2015, H. R. 1687, https://www.congress.gov/114/ bills/hr1687/BILLS-114hr1687ih.xml, pristupljeno 30. siječnja 2017.

22. The Economist, Taxing Sugary Drinks - Stopping Slurping, http://www.economist.com/news/ financeand-economics/21679259-taxes-fizzy-drinks-seem-work-intended-stopping-slurping, pristupljeno 20. svibnja 2017.

23. The Nutrition Health Alliance, Uncapping the Truth: The Mexican Sugar Sweetened Beverage Tax Works, 2016., https://www.sidint.net/sites/www.sidint.net/files/Fact\%20sheet Uncapping\%20 the\%20truth\%20Mexico\%20SSB\%20tax-June2016.pdf, pristupljeno 4. kolovoza 2017.

24. University of Sydney, Could a Sugary Drinks Tax Improve Australian Diets?, http://sydney.edu.au/ news-opinion/news/2016/03/18/could-a-sugary-drinks-tax-improve-australian-diets-.html, pristupljeno 20. prosinca 2016.

25. University of Wisconsin, Population Health Institute and School of Medicine and Public Health, What works for Health - Sugar Sweetend Beverage Taxes, 2017., http://whatworksforhealth.wisc. edu/program.php?t1=21\&t2=12\&t3=73\&id=505, pristupljeno 10. travnja 2018.

26. WHO - World Health Organisation, Controlling the Global Obesity Epidemic, 2017, http://www.who. int/nutrition/topics/obesity/en/, pristupljeno 20. veljače 2017.

\section{C) PROPISI}

Zakon o posebnom porezu na kavu i bezalkoholna pića, Narodne novine, broj 72/2013. 
Rajko Odobaša*

\section{THE EFFECTS OF EXCISE TAX LEVIED ON SUGAR-SWEETENED BEVERAGES ON THE PREVENTION AND CONTROL OF OBESITY}

\section{Summary}

The aim of the research is to determine the reasons for introduction of taxation on production/sales of sugar-sweetened beverages, the current global distribution of these excise taxes across tax areas, and their effectiveness from the aspect of lowering prevalence of obesity and its comorbidities. Excise tax on sugar-sweetened beverages is a tax policy instrument used to prevent and control obesity. From clinical, public health and economic aspects, obesity is a very dangerous disease that affects over 600 million people around the world. It is expected that the introduction of excise taxes on sugar-sweetened beverages, and other "nutritionally empty" foods will have positive effects on changes in consumers' behaviour and the structure of their diet and health. The calories in sugar-sweetened beverages represent a significant source of excessive calories in the diet of a modern man on a global scale and as such lead to the development of obesity. Higher sale prices of taxed beverages should decrease their consumption, consequently diminishing caloric intake, and decrease the prevalence of obesity. Tax revenues can also be used for financing the increasing health care costs in treatment of obesity and its comorbidities, for subsidizing the diet of the poorest population groups and for the production of highly nutritious food. The levying of excise taxes causing a drop in demand of these products would force the producers of sugar-sweetened beverages to improve the quality of their products and change their assortment. The introduction of the excise tax on sugar-sweetened beverages has been disputed, and the opponents question its effects on dietary, health, financial and social sector. Contradictory analysis results of the excise tax efficiency on sugar-sweetened beverages contribute to a burning debate over the introduction of this tax.

Keywords: $\quad$ Fiscal policies, prevalence of obesity, the consequences of obesity, sugar-sweetened beverages, the effects of excise tax

\section{(c) (1) (8)}

This work is licensed under a Creative Commons

Attribution-NonCommercial 4.0 International License.

Rajko Odobaša, PhD, Associate professor, Department of Economics, Faculty of Law, Josip Juraj Strossmayer University of Osijek, Stjepana Radića 13, 31000 Osijek, Republic of Croatia. Email address: rodobasa@pravos.hr. ORCID: https://orcid. org/0000-0002-3438-3893. 